Syntax Literate: Jurnal Ilmiah Indonesia p-ISSN: 2541-0849

e-ISSN: 2548-1398

Vol. 7, No. 1, Januari 2022

\title{
ASIAN INFRASTRUCTURE INVESTMENT BANK AS A PLATFORM FOR CHINA'S POWER EXPANSION
}

\section{Fikram Rettob}

Student of International Relation, Universitas Muhammadiyah Yogyakarta, Indonesia Email: fikram.rettob.isip17@mail.umy.ac.id

\begin{abstract}
China has known as a new rival of the United States of Amerika which has good economic growth. China tries to be a new superpower country in the world, it can be seen since the 1940s when China expands its economy' power to others. But, the goal of China was unsuccessful because of the power of the USA in an economy that hegemony the international institution such Bretton Wood, that goal of China widely spreads when China established the Asia Infrastructure Investment Bank which can be used to challenge Bretton Wood institutions. The aims of this journal to analyze the hegemony and the interest of China behinds the establishing of AIIB, and the aim of AIIB itself. To understand this case deeply, the writer is using dependency theory by Dos Santos which explained the international economic system that only brings benefits for those who had the capital. And this paper is using a descriptive qualitative method which based on secondary data such collecting data from books, journal, and validity news that can be helped.
\end{abstract}

Keywords: hegemony of China; Asian infrastructure investment bank

Received: 2021-12-20; Accepted: 2022-01-05; Published: 2022-01-15

\section{Introduction}

China is undergoing a rapid economic transformation, which makes it a rich and powerful country and can become The New Rival of United America (America's new rival). With a total population of around 1.3 billion, it encourages China to become one of the Asian countries which is the center of the world economy. Countries are eyeing China's rapid economic growth, which has attracted them to carry out bilateral and multilateral relations with China and make China the new axis of global economic power.

In facing the current world economic changes, China has its own strategy to regulate its economic turnover system. As for some of the strategies adopted by China, as written in Joshua Cooper Ramo's hypothesis with the title The Beijing Consensus: There are three strategies adopted by China: First, terms of China's state development must be based on innovation. Second, economic success is not only based on the standard of gross domestic product (GDP) per capita income, but also on its sustainability and quality. Third, self-determination for China itself (Ramo, 2004).

$\begin{array}{ll}\text { How to cite: } & \text { Rettob. F (2022) Asian Infrastructure Investment Bank As A Platform For China's Power Expansion. } \\ & \text { Syntax Literate: Jurnal Ilmiah Indonesia, 7(1). http://dx.doi.org/10.36418/ Syntax-Literate.v7i1.5647 } \\ \text { E-ISSN: } & \text { 2548-1398 } \\ \text { Published by: } & \text { Ridwan Institute }\end{array}$


Based on these strategic elements, the Chinese Government carries out world economic activities based on two interests, namely encouraging the acceleration of economic growth and providing limited space for political freedom for the sake of government stability (Fanny, Arifianti, \& Augusta, 2019).

On this basis, on October 2, 2013, the Chinese Government inaugurated the birth of an international financial institution, namely the Asian Infrastructure Investment Bank (AIIB). AIIB itself is a Multilateral Development Bank (MDB) which is based on modern knowledge and focuses on infrastructure development and productive sectors in the Asian region. Although this bank is named an Asian bank, its members are opened to loyal countries in the world (Fanny et al., 2019). Currently, AIIB has members in 93 countries in the world. The existence of AIIB is one of the complements in financing infrastructure development for member countries in various regions.

AIIB exists as a form of competition with the IMF and World Bank which are considered too conservative and dominated by the United States, Europe, and Japan. The Chinese government announced that the AIIB was formed as an expression of the Chinese government's frustration with the slow pace of global economic reform and governance (Debora, 2017). Therefore, in this study, the author will analyze the motivations behind China in the formation of AIIB.

To understand academic problems, in this study the authors use dependency theory. Dependency according to Dos Santo is a world economic structure that benefits some countries and harms others. Santos explained Furthermore, dependence is a form of state economic power used to dominate other countries (Santos quoted by Ferraro (Ferraro, 2008). There are at least three general definitions used to understand dependency theory. First, dependency draws an international system consisting of two pieces third, the definition of dependency characterizes the relationship between the independent state and the dependent state. Second, a single power that dominates all of them, or commonly referred to as an independent state.

Third, the definition of dependency characterizes the relationship between the independent and dependent countries. Will explain how peripheral countries in AIIB are formed by China.

Cindy Rezma Fanny, Dwi A Nur Arifianti, and Orlandi Daffa Augusta have analyzed their journal with the title "Asian Infrastructure Investment Bank (AIIB) as a New Form of Chinese Hegemony". Explaining that, China, in its competition with the United States in the economic aspect, will experience degradation, often dominated by America (Fanny et al., 2019). So that, be an Iharusan to China forms AIIB to become a new hegemonic force or tool for China for the sake of its economic power.

The journal entitled "Why China Establishes an Asia Infrastructure Investment Bank" written by Daniel Chow explains China's interest in Asia Infrastructure Investment Bank Orders (Chow, 2016), so that Chow's writing can be used as a reference that supports the validity and validity of the author's argument in the journal.

Ren Xiao with his journal-title "China as an Institution-builder: the case of the AIIB" in this journal strongly supports the arguments of the researchers. Because Ren 
Xiao sees that what Wood is like, China must form AIIB to persuade other countries to have more collaboration with dominating China (Ren, 2016).

Wei Liang wrote that the policies carried out by the Xi Jinping government that formed the AIIB embraced China's enormous interests so that it made China an independent country and could make other countries give to it (Liang, 2021). In a journal entitled "China Institutional Statecraft under Xi Jinping, does AIIB benefit China's interests?

"Asian Infrastructure Investment Bank: Assessment" written by Rahul Mishra. Explaining how China's initiative to hang up an institution that can give credibility to countries in need, is also a background that moves China to commit these mistakes (Mishra, 2016).

\section{Methods}

This research uses a qualitative descriptive method. This method, according to Wahidmurni, is a method used to answer research problems related to data in the form of narratives originating from interviews, observation, and data mining activities (Wahidmurni, 2017). Meanwhile, in Mochtar Mas'oed's definition, qualitative descriptive is an effort used to answer the question of who, what, how, where, when, or how much (Moas'oed, 1990).

In effect, the data techniques used by the author are document-based and internetbased archives and research. Archive and document-based research is a type of data based on documents that will be used as material for analysis (Samuel, 2016). Internetbased is a technique of dancing over the internet.

\section{Results and Discussion}

The results that the authors find in this study are that investment assistance by AIIB supplied from China can lead to dependency from third countries that are building up their throes. It is oriented towards China's interests which are used in the form of assistance by AIIB and encourage China's hegemony by these countries.

\section{A. AIIB Order History}

AIIB is an infrastructure that is affiliated with many countries or can be called multilateral with a vision to improve social conditions and in Asia (AIIB, Our Story So Far) (AIIB, 2010) which was formed in 2010 and announced by President Xi Jinping in October 2013 on his journey to Southeast Asia (Insani, 2017). Right on October 24, 2014, 21 countries had stated their disagreement with the AIIB researchers in Beijing (AIIB, Our Story So Far). Then, on 29 June 2015, 57 prospective founding member countries signed the Article of Agreement (AoA) in Beijing (AIIB, Our Story So Far). The UK's decision to join AIIB as the first European country in March 2015 was a pleasant surprise. France, Germany, and Italy expressed their intention to join AIIB as founding members just days after the British government announced its decision. Shortly thereafter, Austria, South Korea, Denmark, Finland, Hungary, Luxembourg, the Netherlands, Poland, 
Portugal, Spain, and Sweden joined the party as founding members. At Harvard University, Philippe Le Corre announces confidently that the AIIB has "divided the West" and is an "American diplomatic catastrophe (Le Corre, 2015). The AIIB's membership of major European countries, Australia, New Zealand, and South Korea is important because it has transformed the AIIB into a genuinely multilateral institution and given the China-led MDB much-needed legitimacy (Liang, China's Institutional Statecraft under Xi Jinping: Has the AIIB Served China's Interest?, 2020). "Candidates for founding members are the names given to 57 AIIB countries that can be seen in the picture below.

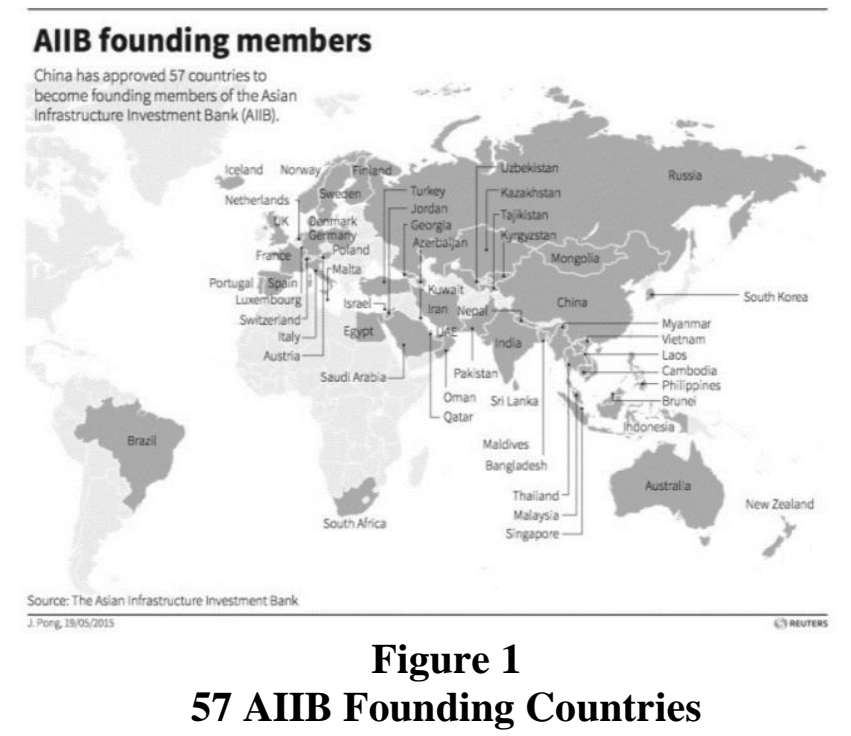

Source: http://www.businessworld.in/article/57-Countries-Join-As-FoundingMembers-Of-AIIB/16- 04-2015-80462/ (Bureau, 2015).

Jin Liquin was elected as President of AIIB through a consensus of 57 countries at the 6th meeting held on August 24, 2015 (AIIB, Our Story So Far). To date, 93 AIIB members are well-known around the world. Although this Bank is domiciled in Asia and its name is Bank Asia, its members are not limited or regulated by region.

\section{B. China's interest in AIIB decoration;}

It is written in the Article of Agreement (AoA) that the objectives of the Asian Infrastructure Investment Bank include two things. First, to promote sustainable economic investment, increase wealth and infrastructure connectivity in Asia. Second, cooperation between regional partnerships and other multilateral developments (AIIB, 2016).

The AIIB function contained in the Article of Agreement (AoA) includes four things. First, private capital is a priority to be promoted to develop infrastructure and productive sectors. Second, use the Diwiyah's resources to become promotional materials to persuade private companies to invest in projects or programs to promote builders in the area. Third, encourage the private sector for economic 
development and support data for loans by private parties who need funds. Fourth, organizing other activities and services that can be possible to support the three functions above (AIIB, 2016).

Although the AIIB was signed by 57 Founding countries. However, as a country that has ideas and pioneers, China may have an interest in establishing AIIB. Several hypotheses are backing China in the AIIB order.

First, as the country with the second-largest economic power in the world, China has only a small influence in world economic institutions such as the IMF, World Bank, and WTO (Chow, 2016). And its economic condition continues to improve until it becomes a competitor to the United States but in the position of China it is not a significant country in the world economic system (Raharyo, 2018). So that this encourages China to look for other alternatives so that it can be significant in the world economic system that is monitored by international institutions, this is one of the reasons why China's AIIB.

The second interest is infrastructure in Asia so that it can accelerate economic growth (Raharyo, 2018).

Third, the increasing need for infrastructure development in Asia has added to China's confidence to prepare AIIB amid a shortage of World Bank funds (Chow, 2016).

The fourth interest, AIIB is a quick response to the dominance of the United States economy in the Asian region (Raharyo, 2018). As it is known that the Chinese Government with the One Belt One Road program and AIIB is a form of the Chinese Government's efforts to balance the power of the United States. In fact, the Aberg hypothesis states that the Chinese Government investigating the United States will detain, reduce leadership, isolate, and insult the Chinese Government internally (Åberg, 2016).

Fifth, the efforts of the United States that continue to rein in China, make China even more confident to spread its hegemony through the AIIB Order, and its Renewal so that the influence of the United States can be limited (Chow, 2016). This can be seen from the US allies who refuse US political invitation not to join AIIB.

Sixth, China can use AIIB to achieve its national interests with Xiaoping's most famous approach regarding foreign policy, namely Taoguang Yanghui, which tries to remain humble to achieve its interests (Bob, 2015). Bob explained that some of the national interests that China wants to address are; (i) political stability, (ii) security and sovereignty, (iii) sustainability in economic and social development (Bob, 2015).

Seventh, AIIB can be used as a platform for promoting the one belt one road strategy from China. One belt one road itself is the construction of a new Silk Road that forms relations between Central Asia, the Middle East, and Europe as well as Southeast Asia and Africa through the Indian Ocean for the sake of smooth trade relations between countries (Bob, 2015). 
Eighth, to disseminate the flow of capital obtained from China so that China can easily be the people who are in the national territory described above.

\section{AIIB Financial System;}

The system used in the AIIB process is based on three strategies, namely, lean, clean, and green. Lean means skilled staff and an efficient management team. Cleaning up organizations that are ethical and have zero tolerance for corrupt practices. Green, which means that infrastructure development must be based on the principle of respect for the environment (Bob, 2015).

The financial system in AIIB is not much different from other financial systems of the Multinational Development Bank. Like other MDBs, AIIB capital comes from grants and members (Bob, 2015).

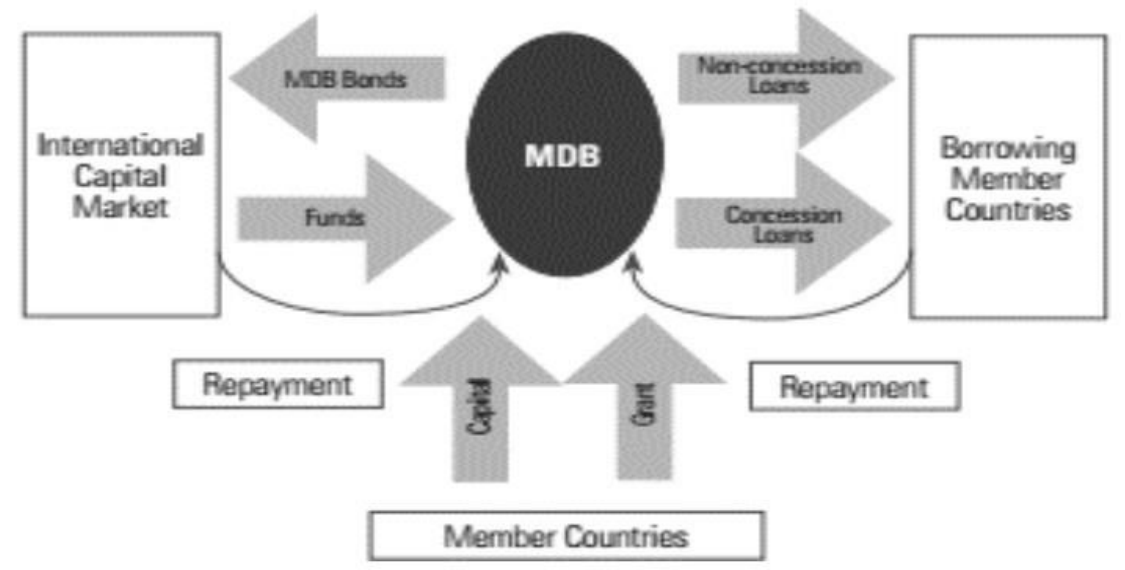

Figure 2

MDB financial system

Source: Bob et al., Asian Infrastructure Investment Bank: China as Responsible Stakeholder

But there are differences between AIIB and MDB that have been there before. First, AIIB has a license and a relatively larger capital subscription. Second, the largest shareholder comes from the Asian region, which has more than $70 \%$ capital. Third, AIIB does not have a board of directors as we find in other MDBs which are more inclined to have a strong governance structure. Fourth, the capital taken from the capital subscription is $20 \%$, which is bigger than other MDBs, except for EBRD and CAF. Fifth, a different concentration from other MDBs, which concentrate on poverty, reduction, sustainable development, and social development. Meanwhile, AIIB concentrates more on infrastructure investment and connectivity (Bob, 2015).

\section{AIIB systems for projects in countries of need;}

Countries wishing to obtain or borrow funds from AII must go through and fulfill at least six stages for project development. The first stage is strategic programming which aims to analyze or review ideas and proposals from the proposing parties. When the project has met the initial screening criteria it will continue in a rolling investment process which is then approved and approved by 
the Executive Committee. The second stage is project identification, namely submitting a document summary of the project and a feasibility report. After this information is obtained, it will allow the Bank to research to ensure the validity of the information in the form of field visits. The stage is project preparation, where parties from AIIB and institutions or institutions or those making loans will collaborate in project design and this will be carried out by the AIIB team which will be followed up with the preparation of the MoU document after conducting an internal review. The fourth stage is board approval, namely the negotiation process between the borrower and AIIB, and project documents will be submitted to the AIIB Board. But borrowing can be effective when it has fulfilled the authority of borrowing. The fifth stage is project implementation, namely project implementation that debates the full history of the AIIB parties. The sixth stage is project completion and evaluation, which is the final process that requires the AIIB team to provide a project completion report to the Board of Directors (AIIB, 2016).

\section{E. Dependence on AIIB;}

The efficient bureaucracy system and the reduced interest offered by AIIB make developing countries participate and become members of AIIB. On the other hand, this is a change from their dependence on AIIB. The loan money obtained by developing countries from AIIB is used to build infrastructure. From this, as the originating country of the AIIB, it has made many developing countries integrated directly with China. On the other hand, this is what corrects China's hegemony in developing countries because they have to strengthen relations with China to smooth their way in making loans at AIIB. And we can see program the Project of China's Government that is known as Belt and Road Initiative which implemented to most countries, and those countries should be accepted it, in order to strengthen their relation, and existence as members of AIIB.

\section{F. Project of One Belt, One Road Initiative, and relevance with AIIB;}

As we already know, the government of China is building an economic strategy with the motive of constructing a silk route to smooth trade and economic crossings between countries. This strategy is formulated or conceptualized in the form of a megaproject which we know as One Belt, One Road (OBOR), or the Belt and Road Initiative (BRI).

The SREB was announced by Xi Jinping as the OBOR's "land arm," to rejuvenate the Eurasian route by connecting China with Central Asia, West Asia, Russia, and Europe, while the maritime arm, the 21st Century MSR, aims to establish ports along the maritime route from China and Southeast Asia to South Asia, Africa, and the Indian Ocean Region (IOR). Interestingly, Xi Jinping announced both the MSR and the AIIB from the same network. Xi Jinping highlighted policies related to the OBOR initiatives in February 2015, emphasizing that the AIIB's primary mission is to provide capital for OBOR and other related initiatives (Xinhua, 2015). This demonstrates China's willingness to use AIIB funding to connect infrastructure projects under the OBOR system (Mishra, 2016). 
China has already announced a US\$40 billion Silk Road Fund for OBOR infrastructure projects, as well as a willingness to create a second bank, the 'Maritime Silk Road Bank,' which would effectively finance the AIIB if it were to be established. The AIIB will also act as the OBOR's funding arm, with an estimated budget of US\$1.4 trillion, about 12 times that of the Marshall Plan (currently worth around US $\$ 120$ billion) (Mishra, 2016). In terms of the Chinese economy, Beijing aims to invest in the hardware and software of regional connectivity to boost its exports. This, in turn, would boost domestic output and consumption demand (Wong, 2015).

OBOR seeks to achieve China's politico-strategic and soft power dominance through regional and global integration, while AIIB is an effort by the Chinese leadership to foster China's economic influence around the world. Both initiatives aim to solidify China's place in the global political, strategic, and economic environment. According to China's official statements, developments under OBOR and through the AIIB are part of a larger picture aimed at encouraging further economic integration of participating countries and the establishment of a new regional economic trading and investment bloc, as well as expanding the global use of the Chinese currency, resulting in the Renminbi's rapid internationalization (Wong, 2015). Such arguments in favor of OBOR, however, ignore the security situation in China's neighborhood. Over the past few years, China's neighboring countries, such as Pakistan and Afghanistan, as well as neighboring areas, such as West Asia and Central Asia, have experienced turbulence. Instability in the neighborhood can make it difficult for Chinese investments to thrive (Mishra, 2016).

\section{G. AIIB as a form of China's leadership in the field of regionalism;}

The concept of leadership is a concept that develops continuously in the international and national world, this concept spreads widely to all corners of the world after the second world war, where many countries have just received their sovereign rights and also their independence, thus encouraging superpowers and countries that have the power to protect its existence as a large country and has influence over others. The concept of leadership itself can be said to be a concept that has a close relationship with hegemony, but the concept itself is not like the concept of hegemony. The concept of leadership does not believe in the traditional system of power. There are at least three models that can be used to understand the concept of leadership;

The first model believes that a leader usually has a high level of real strength or hard power. A large number of military personnel, the vast territory, and the economic capability determine the hard power of a country. The first model also believes that the existence of global governance is zero, therefore, a leader is the same as the hegemon concept in the definition (Raharyo, 2018).

The second model believes that leadership will be based on a country's initiative on certain common issues or can act as a mediator on any issue among 
members. This model is usually related to a leader's responsibility to provide public goods. Unlike the first model, the second model is open to countries without high levels of hard power. This opens opportunities for small or secondary countries to take the opportunity as leaders in the region or, which brings us to the third model, the cooperative model (Raharyo, 2018).

The third model or the cooperative model believes that leadership can be carried out by more than one country. The second model has the same belief that a leader does not rely on hard power. Besides, the third model emphasizes acceptance or approval by other countries that one or several countries are important as leaders (Keohane, 1984).

A leadership system that is run smoothly, when the actors form a region or region to build leadership that influences other countries which are categorized in the region or region. So, to understand the regional concepts around China is a basic form of understanding China's leadership through AIIB.

For that, the author will explain a little about the region. Regional formation generally requires a 'supply-demand side, without each other the regional processes are incomplete. The demand side is indicated by groups or individuals who demand a regional institutional movement, usually those with an interest in lowering tariffs and non-tariff as well as transaction costs. Meanwhile, the supply side is shown through "good politics to provide leadership, combine interests, and policies" (Choi, 2007).

To understand China's efforts to become a leader in the East Asian region, we must see how the process of East Asian regionalism was initially seen by looking at its institutional development. We must return to Post World War II where countries in the East Asian region began to gain independence and try to develop their economic conditions.

East Asia, which consists of two sub-regions, Southeast Asia and Northeast Asia, with different conditions after World War II. The northern part is many conflicts with the Korean War and the development of each country, causing countries in Northeast Asia to focus on stabilizing domestic politics. Meanwhile, the southern part, which is classified as a newly independent country with Thailand, Malaysia, the Philippines, and Indonesia, at least has a better national stability condition and can establish international relations with its neighboring countries. The formation of the Southeast Asia Treaty Organization (SEATO) was the first sign of the establishment of a regional institution in Southeast Asia, seen with the Association of Southeast Asia (ASA) and Maphilindo in 1954, 1961, and 1963. However, the initial movement was temporary and quickly disbanded. long after it was founded (Raharyo, 2018).

The presence of AIIB in the Asian region or region which was initiated by China, presenting a form of Chinese leadership that has been discussed in three leadership models that can be used to influence and control countries that depend on AIIB. The concept of the first leadership model states that an economy is a tool 
for making other countries if examined by AIIB, is a financial institution that is oriented towards economic development through a loan system with a small interest. The second model of leadership is the same problem, as it has been stated that the main problem of developing countries in Asia or on other continents is financial complaints and dissatisfaction of these countries to Bretton Woods Institutions which provide loans with high interest and administration representing troublesome or troublesome, then AIIB is present as a form of response to these complaints together, and China sees this opportunity as a form of leadership. The third model focuses more on negotiation and structural forms in all respects, meaning that to gain leadership authority, a forum or media is needed to learn and facilitate control over others, whose forms have given themselves to both the container and the media. This means that AIIB is a medium or media used by China to teach its leadership without any coercion against members who give themselves up to be part of this AIIB.

\section{H. China as a competitor to the United States;}

The policies of the Chinese Government in the last decade can be taken as China's policy to become a leader in the East Asia Region and to dim the spread of United States hegemony (Raharyo, 2018). The Chinese government's efforts are the basic foundation that China is present in the international world as a competitor to the United States. We can see also this through the US foreign policy which tends to pressure the Chinese government.

There are several reasons why China regulates AIIB as a form of competition with the United States, but in this study, the author will explain only three reasons: First, the formation of AIIB by China as a provider of public space for the Asian region to form a power based on regionalism and oriented values. on unity and unity led by China. Second, China has been trying to compete with the United States since China opened multilateral relations with ASEAN, this is seen as a form of competition that China has launched for the United States. The dominating international complaint is dominated by the United States in the international world, so China forms AIIB with an easier system and lowers interest rates compared to the IMF or the World Bank making countries join AIIB and this is what makes the United States make China its competitor (Raharyo, 2018). Based on the three reasons above, the international community considers China as the new rival of the United States of America.

\section{Chinese hegemony;}

The AIIB's establishment is widely regarded as a significant diplomatic achievement for China, which has been attempting to position itself as a major responsible stakeholder in the international system. China's greatest accomplishment is that it has not only been perceptive enough to recognize the developing world's perceived underrepresentation, but it has also been able to recognize Asia's conspicuous infrastructural deficit. '[t]he AIIB will allow China to take on more global responsibilities and contribute to making the existing global 
economic governance framework more just,' said Xi Jinping. '[t]he AIIB will allow China to take on more global responsibilities and contribute to making the current global economic governance system more equal, fair, and efficient,' said Xi Jinping (Teo, 2016).

The ease and low-interest system have persuaded countries to join AIIB members, to obtain funds to be used to build infrastructure. This can be done with young people if they have a close or special relationship with China. On the other hand, when they want to build this relationship there will be a dependency on China. Through this dependency system, China uses it as a platform for demonstrating the country to suppress the spread of United States hegemony.

\section{Conclusion}

The establishment of the AIIB as the MDB which was initiated by China has persuaded 93 countries that have participated as members, and as MDBs that are quite successful in their regions. And the system used in AIIB to make it easier for other countries to invest and borrow at a lower interest rate. So that China as an AIIB initiative country is approached by other countries that need assistance. This is what makes China a new power in the economic aspect and a competitor to the United States.

AIIB itself exists as a form of China's power to compete with the dominance of the United States in international institutions or Bretton Wood's Institutions such as the IMF and World Bank. This institution captures China as a form of United States hegemony for its national interests and spreads its power. 


\section{BIBLIOGRAPHY}

Åberg, John H. S. (2016). A struggle for leadership recognition: The AIIB, reactive Chinese assertiveness, and regional order. Contemporary Chinese Political Economy and Strategic Relations: An International Journal, 2(3), 1125-1171. Google Scholar

AIIB. (2010). Our Story So Far. Retrieved Agustus 26, 2020.

AIIB. (2016). sian Infrastructure Investment Bank, Articles of Agreement. Retrieved $\begin{array}{llll}\text { Agustus } & 26,20 . & \text { Retrieved }\end{array}$ from\%0A/var/folders/nl/g4d3xnk9203f80s7q40cwxzr0000gp/T/com.apple.Preview /com.apple. Preview.PasteboardItems/5321-9073-3-PB (dragged).pdf

Bob, Daniel E. (2015). Asian Infrastructure Investment Bank: China as Responsible Stakeholder? Sasakawa Peace Foundation USA. Google Scholar

Bureau, B. O. (2015). 57 Countries Join As Founding Members Of AIIB. Retrieved Agustus 26, 2020.

Choi, Young Jong. (2007). Northeast Asian Regional Integration. The Korean Journal of International Studies, 5(1), 113-129. Google Scholar

Chow, Daniel C. K. (2016). Why China established the Asia infrastructure investment bank. Vand. J. Transnat'l L., 49, 1255. Google Scholar

Debora, Y. (2017). AIIB, Penantang Baru Bank Dunia dan IMF dari Cina. Retrieved August 25, 2020.

Fanny, Cindy Rezma, Arifianti, Dwi Nur, \& Augusta, Erlandi Daffa. (2019). Asian Insfastructure Investment Bank (AIIB) Sebagai Bentuk Hegemoni Baru Tiongkok. Nation State: Journal of International Studies, 2(1), 71-87. Google Scholar

Ferraro, Vincent. (2008). Dependency theory: An introduction. The Development Economics Reader, 12(2), 58-64. Google Scholar

Insani, N. \&. (2017). Prospek Implementasi Asian Infrastructure Investment Bank (Aiib) Terhadap Peningkatan Kerjasama Ekonomi Tiongkok Di Asia Tenggara (Studi Kasus : AIIB di Indonesia Dan Myanmar). Skripsi Makassar: S1 Hubungan Internasional Universitas Hasanuddin. Google Scholar

Keohane, O. R. (1984). After Hegemony: World Political Economy Cooperation and Discord. New Jersey: Princeton University Press. Google Scholar

Le Corre, Philippe. (2015). Dividing the West: China's new investment bank and America's diplomatic failure. Brookings Institute (17 March 2015), At< Https://Www. Brookings. Edu/Blog/Order-from-Chaos/2015/03/17/Dividing-theWest-Chinas-Newinvestment-Bank-and-Americas-Diplomatic-Failure $>$ (Searched 
Fikram Rettob

Date: 30 April 2019).

Liang, Wei. (2021). China's Institutional Statecraft under Xi Jinping: Has the AIIB Served China's Interest? Journal of Contemporary China, 30(128), 283-298. Google Scholar

Mishra, Rahul. (2016). Asian Infrastructure Investment Bank: An Assessment. India Quarterly, 72(2), 163-176. Google Scholar

Moas'oed, Mohtar. (1990). Ilmu Hubungan Internasional: Disiplin dan Metodologi Dictionary. Jakarta. LP3ES. Google Scholar

Raharyo, Anggara. (2018). Asian Infrastructure Investment Bank (AIIB) as an Instrument for Regional Leadership of China in the East Asia Region. AEGIS: Journal of International Relations, 2(2). Google Scholar

Ramo, Joshua Cooper. (2004). The beijing consensus. Foreign Policy Centre London. Google Scholar

Ren, Xiao. (2016). China as an institution-builder: the case of the AIIB. The Pacific Review, 29(3), 435-442. Google Scholar

Samuel. (2016). Metode Pengumpulan Data Dalam Penelitian. Retrieved Agustus 25, 2020.

Teo, E. (2016). AIIB kicks off with $\$ 72 m$ boost from China. The Straits Times Asia (STa).

Wahidmurni. (2017). Metode Penelitian Kuantitatif. Retrieved Agustus 25, 2020. Retrieved from from repository.uin- malang.ac.id/1985/2/1985.pdf

Wong. (2015). China to widen its economic influence by one belt, one road. HSBC Global Connection. Google Scholar

\section{Copyright holder:}

Fikrom Rettob (2022)

First publication right:

Syntax Literate: Jurnal Ilmiah Indonesia

This article is licensed under:

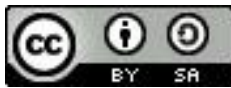

